\section{Digital Printing in Contemporary Art. A review for conservation decision-making}

\section{Impressão Digital em Arte Contemporânea. Uma revisão para decidir sobre a sua conservação}

\section{IRAIA ANTHONISEN- AÑABEITIA ${ }^{1 *}$ ITXASO MAGUREGUI OLABARRIA $^{1}$}

1. Fine Art Faculty. University of the Basque Country (UPV/EHU), Department of Painting, Lejona, España

*iraia.anthonisen@ehu.eus

\begin{abstract}
Art uses the contemporary tools developed at the time, because of their material and conceptual possibilities. Comparing with other media, computers and output devices have transformed our society and culture in the last decades more than ever. These resources offered an interesting research path for artists, generating consideration and discussion concerning its use and conservation. On this regard this paper focuses on two main aspects: the materials employed to produce digital prints (technologies, inks, substrates, finishing and mounting) and conservation issues such as terminology concerns, documentation and recording, longterm stability, and reproduction matters. Clear standards are needed in order to guarantee the conservation of these artworks, representative of this century.
\end{abstract}

\section{Resumo}

A arte utiliza as ferramentas contemporâneas desenvolvidas na época, pelas suas possibilidades materiais e conceituais. Comparando com outros meios de comunicação, os computadores e os dispositivos de saída transformaram a nossa sociedade e cultura mais do que nunca nas últimas décadas. Esses recursos ofereceram um interessante campo exploratório para os artistas, gerando considerações e discussões sobre seu uso e conservação. Nesse sentido, este artigo está focado em dois temas principais: os materiais usados para produzir impressões digitais (tecnologias, tintas, substratos, acabamentos e montagens) e as questões de conservação, como o cuidado na terminologia, documentação e gravação, estabilidade a longo prazo, e problemas de reprodução. São necessários procedimentos claros para garantir a conservação dessas obras de arte, representativas deste século.

\section{KEYWORDS}

Printing technologies Digital print terminology Data-recording Reproduction Conservation

\section{PALAVRAS-CHAVE}

Tecnologias de impressão Terminologia de impressão digital Registo de dados Reprodução Conservação Museus de Arqueologia 


\section{Introduction}

The first computer-based graphics at the beginning of the sixties laid the foundations for new developments in contemporary art, intended to change aesthetic concepts as photography did for a long time.

Computer graphics, in its early years, were mainly performed by scientists belonging to research centres or under their direct supervision due to the low availability of computers. Therefore, few artists had the chance to use them for creative purposes [1-2]. The arrival of personal computers, the first non-impact printing systems (NIP) and the first design software in the eighties allowed not only the artist, but also the general public to employ a tool previously restricted to a few [3].

These works, considered a secondary product of the artists' creative activity did not earn the trust of art collectors or those interested in the arts [4]. At present, computers and digital printing technologies are ubiquitous and this situation has normalized their use. A variety of artworks of digital nature - photographs, prints, sculptures, installations - is increasingly entering contemporary art museums and private collections. As this happens, new challenges appear to collectors and restorers, preceded by the creative experimentalism, the lack of attention to the employed creative processes or technologies, and the correct identification. Furthermore, constant evolution of the available technologies and materials push conservators to apply new methods to properly take care of digital prints [5].

Since the 1990s the use of digital printing technologies has been an indisputable part of the creative processes of artists. As these artworks have been entering in museums and other collections, some issues concerning their conservation started raising, such as the interest towards the creative process, material composition and ageing.

Conserving contemporary art is a complex issue; according to contemporary theories [6] not only the conservation of the object remains important, its conceptual features, including the intentionality and meaning, should be also keep intact in order to maintain the integrity of the artwork. Therefore, this review focuses on reflecting about previous research concerning digital printing technologies and materials that constitute contemporary artworks, that is the materiality; identification and characterization of the technologies and materials on the one hand, and exhibition and mounting issues on the other hand, all of which affect the conservation of digital prints. In addition, intangible values regarding artists' intention should be taken into account, as an essential part of a thorough conservation plan.

\section{Digital Printing Technologies and Materials}

Four aspects are important to take into account about the materiality of digital prints: 1) printing technologies; 2) inks; 3) substrates; and 4) finishing and mounting systems.
The interaction between them is crucial to choose the most appropriate conservation measures [7] so, having deep knowledge of these four main areas is essential before making any decision.

\section{(1) Digital printing technologies}

At present three main digital printing technologies exist: electrophotography, inkjet and thermal (sublimation) [8].

At the beginning of the new millennium several publications show the interest that digital printing technologies generate in the graphic industry and other more technical areas [9-10]. They provide detailed information on the different technologies and their functions, and a timeline about ink and printing substrates.

The continuous research production focuses on the optimization of the technologies, making it possible to find countless references about these issues. Most of them focus on inkjet, as it is the most versatile technology in terms of fields or disciplines in which it has application. It ranges from the graphic industry itself, electronics and electricity, to areas such as medicine and biology [11-12], but in most cases the artistic point of view is not analyzed [13].

Likewise, The Inkjet Conference, a series of international conferences organized by the European Specialist Printing Manufacturers Association (ESMA) - which takes place since 2014 in Düsseldorf and since 2018 in Chicago - focus on aspects related to engineering and chemistry that have or will have impact on inkjet prints [14]. Despite the great interest of these conferences, their specificity and technical nature do not make them especially relevant for the research related to Digital Fine Art Printing.

Conversely, trade fairs appear to be very interesting resources to get up-to-date first-hand information about the development of new products, equipment and materials that printing laboratories could acquire, and therefore, that artists will use. In the international arena, it is worth mentioning DRUPA, the most important fair worldwide on printing technologies which takes place every four years in Düsseldorf [15]. The fair welcomes manufacturers of the most important brands in the sector such as EIZO, HewlettPackard, Xerox, Epson, Canon, Konika Minolta, Roland and Océ, being also the place to present the latest developments worldwide, that later will be presented at other fairs.

\section{(2) Inks for digital printing}

The three digital printing technologies, previously mentioned, use different types of ink. Their availability for artistic purposes has been directly influenced by the price of the equipment, the development of the technologies, the quality of the final image as well as its conservation; the location of the inks in the support, their interaction and their resistance towards external agents have direct effect on the latter. Until inkjet printers appeared in the market, electrophotography played an important role for lots of artists. In this case, the colouring substance is a powder 

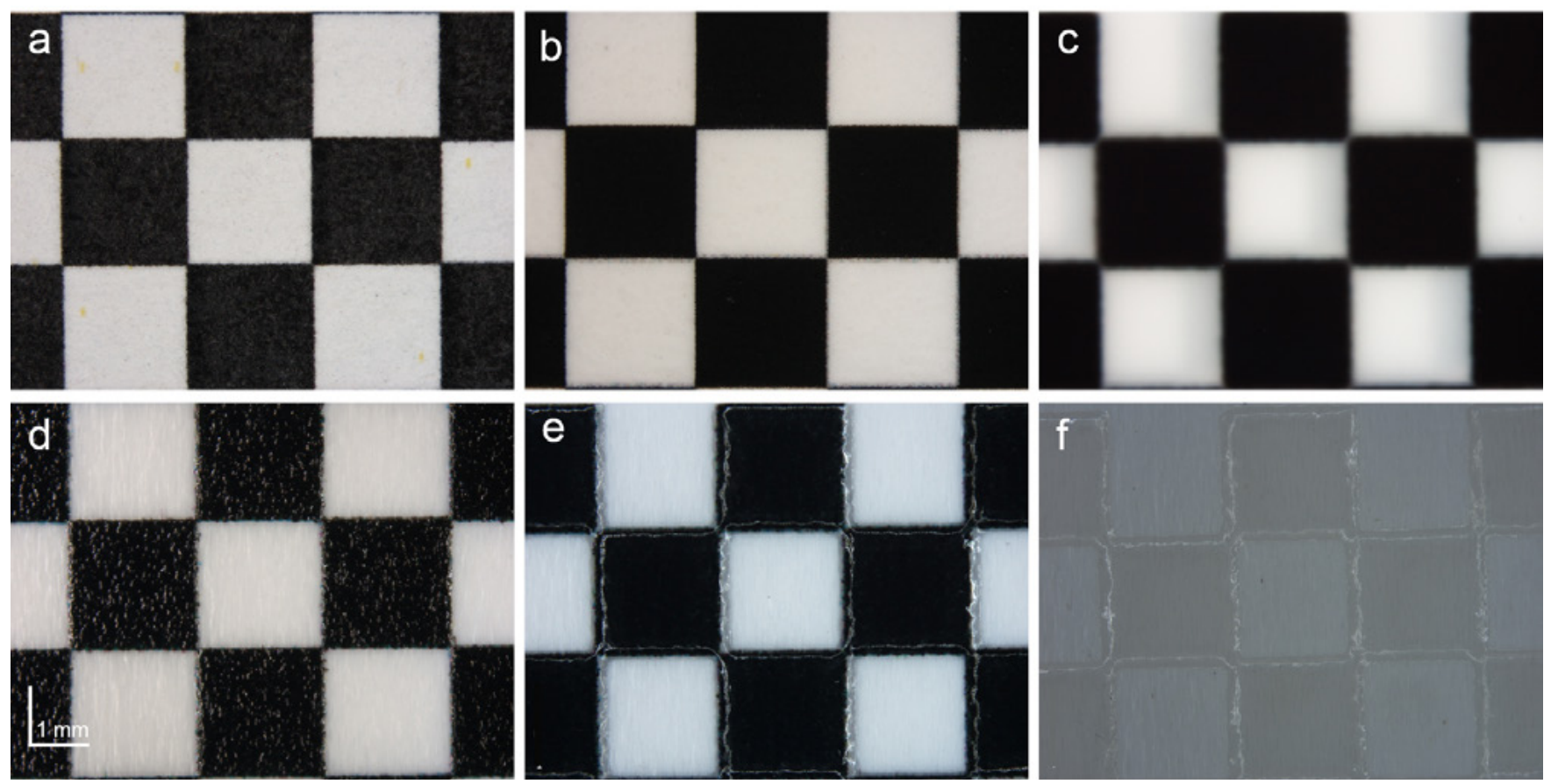

Figure 1. Microscopic images show surface variations caused by different ink-substrate combination that will affect its conservation. Note the differences between the row above, in which the ink is embedded in the support or IRL, and the bottom, in which the ink is deposited on the surface, generating images that show some relief to the touch. a) Toner on plain paper; $b$ ) Water-based pigment inkjet ink on matt Fine Art paper; $c$ ) Water-based (dye) ink on aluminium (sublimation process); d) UV-curable inkjet ink on PVC; e) UV-curable inkjet ink on PVC + 5 gloss layers; f) UV-curable inkjet ink on PVC, only 5 gloss layers.

called toner, which melts and adheres to the substrate, usually plain paper, changing the surface gloss of the printed areas (Figure 1a). When inkjet became accessible to artists, new ink formulations made it possible to print on a wider range of materials, from flexible to rigid. Currently, although water-based pigment inks are the most popular to print on paper substrates (Figure $1 b$ ), inkjet allows to use diverse ink types - solvent based, oil based, UV curable, latex inks and phase change - that influence the surface appearance. As noted in Figure $I(d, e$ and $f)$, UV curable inks enable different surface finishes, illustrating the difficulties that just one ink type could generate regarding its conservation. In recent years thermal (sublimation) technologies are becoming popular despite its price due to its similarity to photographic continuous tone image quality. In this kind of print, waterbased dye inks are embedded in the ink receiving layer (IRL) of the substrates; as shown in Figure $1 c$, looking at samples under magnification the edges of the black squares show a fuzzy appearance because of the small particle size of the colorants. This is a helpful clue to identify the main process and differentiate it among the other technologies.

Magdassi [16] delves into the various aspects to be taken into account in the ink design: the selection of the most appropriate colorant type, surfactants, viscosity rate or ink drying method. Variation in components and proportions are selected in order to offer the widest colour gamut, best colour saturation and stability against atmospheric agents or abrasion. This is the reason why formulations develop constantly to accomplish the most stable inks. Examples of this complexity are shown in papers related to phase-change inks [17] or others who expand on the differences and similarities between dye-based and pigment-based inks [7, 18]. The first formulations for inkjet printers employed dyes due to its high colouring power, wide gamut and vibrant colours, but it was soon discovered that their stability to light was quite low, which caused rapid discoloration of the images, even complete fading [19]. This problem led chemical engineers to start using pigments as colouring agents, which meant difficulties related to grain particle size, more limited colour gamut and less colour saturation, demanding new approaches and improvements. It should be noted that ink manufacturing is an industry in constant evolution and riddled with patents, so it is very difficult to find data about specific ink brands. Therefore, in most cases, conservators only have a rough idea about the ink composition (Table I).

\section{(3) Substrates for digital printing}

Advances made in the field of ink designing allowed the use of a growing variety of substrates specifically designed for each digital printing technologies, ranging from papertraditional handmade or industrially manufactured-to other materials such as plastics, glass, metals, textiles and so on. The most employed substrates are specifically designed for inkjet printers because of the versatility of the technology. Among them, paper still leads the demand for digital fine art printing; many types rely on pre-existing substrates that have been modified to adjust to new technologies and thus, cover a growing demand. For that, it is necessary to have a good understanding about the interaction between inks and substrates [20] in order to generate specific coatings capable 
Table 1. Main components of the inks for electrophotography, inkjet and thermal (sublimation).

\begin{tabular}{|c|c|c|c|}
\hline Technology & Colorant & Vehicle/binder & Aditives \\
\hline Electrophotography & Organic pigments & $\begin{array}{l}\text { Styrene and acrylate copolymer } \\
\text { (usually) }\end{array}$ & $\begin{array}{l}\text { - Charge control agents } \\
\text { - Silica/Titanium (flow properties) } \\
\text { - Zinc stearate (surfactant) } \\
\text { - Waxes/Silicone oil (release agent) }\end{array}$ \\
\hline Inkjet & Organic pigments & $\begin{array}{l}\text { Depends on the ink type: } \\
\text { - Water-based } \\
\text { - Solvent-based } \\
\text { - Oil-based } \\
\text { - UV curable } \\
\text { - Latex } \\
\text { - Phase change }\end{array}$ & $\begin{array}{l}\text { - Co-solvents } \\
\text { - Surfactants } \\
\text { - Biocides } \\
\text { - Chelating agents } \\
\text { - Anti-corrosion additives }\end{array}$ \\
\hline Thermal (sublimation) & Disperse dyes (usually) & Water-based & $\begin{array}{l}\text { - Co-solvents } \\
\text { - Dispersants } \\
\text { - Surfactants } \\
\text { - Biocides } \\
\text { - Defoamers } \\
\text { - Buffers }\end{array}$ \\
\hline
\end{tabular}

of receiving and containing the inks, known as IRL, on which there has been some research [21-23]. This makes it possible to offer a wide range of surfaces with specific characteristics in terms of paper grade, roughness, whiteness, brightness, opacity and $\mathrm{pH}$ that determine the appearance of the print and its conservation over time.

Fine Art papers, usually employed in traditional techniques such as watercolour or engraving have evolved to adapt to electronic devices, so that traditional paper mills such as St Cuthberts Mill in Somerset, United Kingdom [24], Hahnemühle in Solling, Germany [25] or Canson in Annonay, France [26] offer an interesting variety of papers for inkjet printing while preserving the manual process that characterizes them. Other types, such as baryta (also known as fibre based, FB) or Resin Coated (RC) papers, which have their origins in the nineteenth century and the late sixties of the twentieth century photography respectively, have also been modified to continue maintaining the physical appearance of traditional photographic techniques in the images produced by means of inkjet devices.

In order to guarantee the stability of the printed images over time, equipment manufacturers also have designed their own paper substrates [27-28] to offer the greatest compatibility between their devices, inks and substrates. Other companies, such as the German Tecco [29] have also conditioned part of their production to inkjet technology.

On the one hand, thanks to UV curing, latex or solvent inks, other types of substrates, which mainly come from industrial use, can be directly printed on. Among them the most popular are polyvinyl chloride (PVC), polymethyl methacrylate (PMMA) or aluminium composite materials (ACM). Even if its use is not as widespread as traditional substrates like paper, UV technology is becoming more attractive for artists because of the displaying possibilities it offers, including hanging or attaching the artworks directly to the wall and avoid framing (Figure 2).

Moreover, other tools such as computer controlled CNC cutters are also being employed for specific works requiring cutting of more or less intricate shapes (Figures $2 b$ and $2 c$ ).

\section{(4) Finishing and mounting systems}

At present, large print formats seem to be a tendency among artists. In order to display these, artists apply different finishes on their surfaces and select specific mounting systems which enhance their complexity and poses new challenges to conservators and restorers (Figure 3).

There are many finishing options to cover the surface of the prints: film, liquid or spray laminates. Usually they are employed for protective purposes against humidity, light, air pollutants, abrasion or fingerprints. They can also be applied with the intention to modify the surface to correct the differential gloss, eliminate glare or improve colour depth and intensity.

On the other hand, mounting substrates [30] consist of adhering permanently a rigid material to the artwork so that it helps in its exhibition, handling and storage; these techniques provide the prints a flatness that cannot be achieved in a traditional framing, but also rigidity, eliminating the need to use heavy glazing and reducing the production cost. This is the reason why many artists decide to use them.

According to these possibilities, prints in museum and private collections can be found as they are obtained from the printer or with some added materials on the front (face 

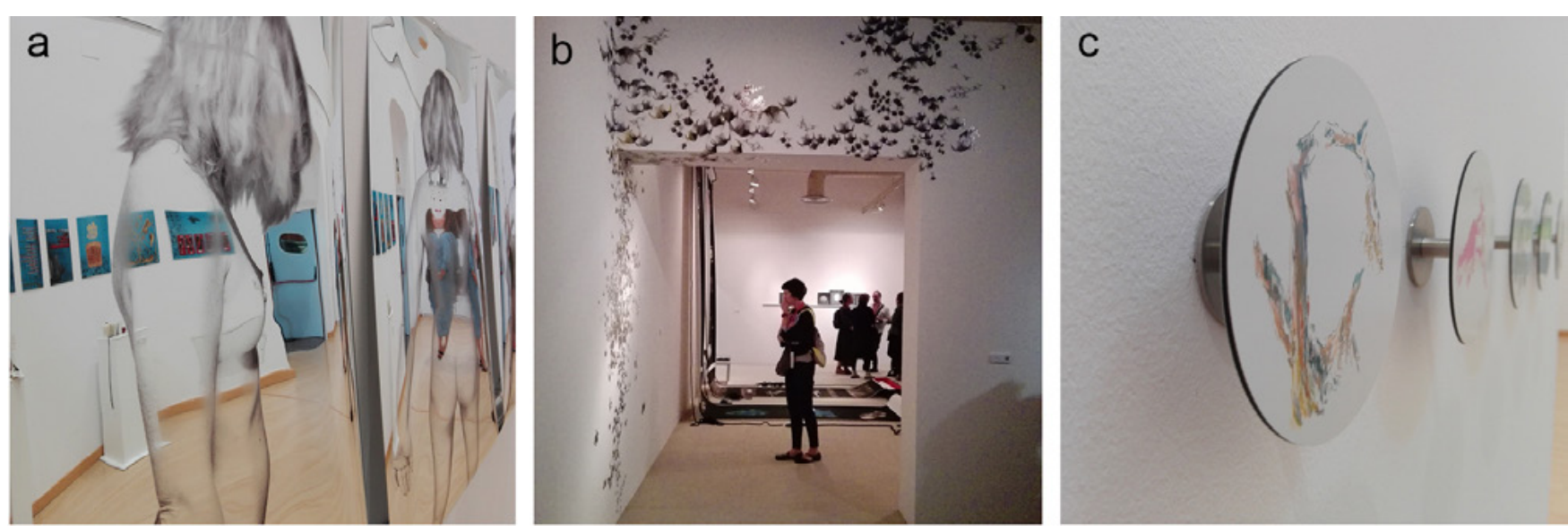

Figure 2. Alternative substrates to paper employed by artists for digital printing: $a$ ) Mirror-like plastic in Adriana Cora's El cuerpo como espejo (2018) (detail); b) adhesive vinyl in Marcela Caballero's Graphobios (2013-ongoing); c) Printed Dibond in Marina Mangubi's Biathlon-in-print (2016) (detail).
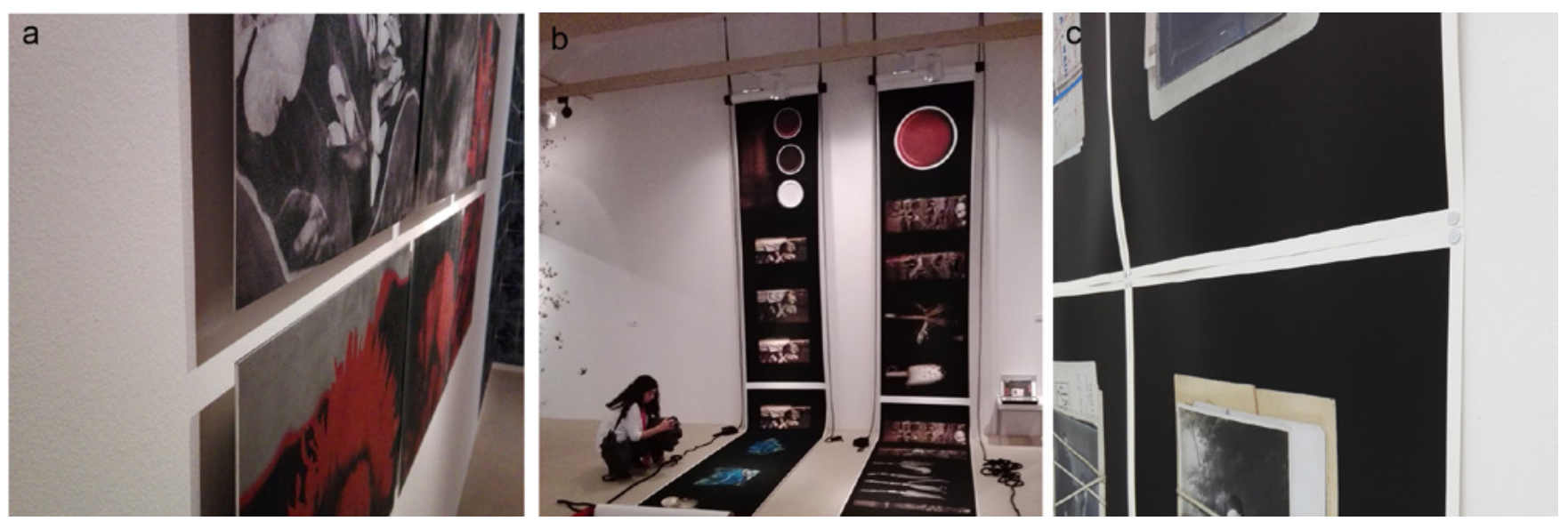

Figure 3. Different mounting systems employed in exhibitions: $a$ ) Mirta Gendin Real I-Real (detail), printed aluminium (2016); $b$ ) Anita Jensen's Folding and unfolding the scrolls of life between times and places, printed continuous paper roll hanging from the roof and unrolled on the floor (2017); c) Judith Martinez Estrada, El apartamento: lugar, procedencia e identidad, printed fine art paper attached to the wall using pins (2018).

mounting), on the back, or on both sides (encapsulated) of the printed image (Figure 4) [31-33].

However, it should be kept in mind that all finishing and mounting systems employed to modify the surface are irreversible, so deterioration in them could have direct consequences in the conservation of the artworks. Moreover, its effects and interactions with the printed substrate have not been properly studied, except on specific cases [34-36].

\section{Digital Print Conservation Issues / Contemporary Art Conservation Issues}

The technologies available for digital printing and the development of new materials entail some important issues about terminology, appearance of the artworks and the need for accurate documentation and reproduction as a conservation strategy.

\section{Terminology concerns}

The presence of digital prints in museum and institutions has significantly increased in recent decades, shaping the collections of many museums around the world such as the Victoria and Albert Museum (V\&A) in London, which houses a complete collection of computer-generated art ranging from the first artists to modern creations.

These prints constitute a significant part of the cultural heritage of our time and this is why they will continue to be frequently acquired by public and private institutions and collections. Museum professionals responsible for the acquisition, exhibition and preservation of digital prints, often face the problem of having to manage works whose materiality and behaviour is not yet known in depth.

In 2008, a study conducted in the United States revealed that there was no standardized or agreed definition among the professionals involved in the art world of what digital printing is, and it was clear, the difficulty that existed to differentiate between a digital print and one that is not [37].

This lack of knowledge regarding digital printing technologies and the materials that constitute them entails that many works are not properly identified and characterized, and therefore, they are stored for what they seem and not for what they really are. Judging the terminological differences found among institutions and 
a

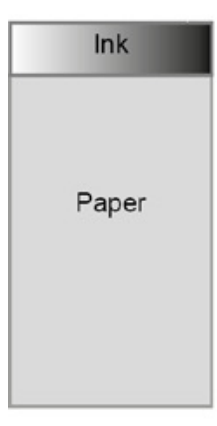

b

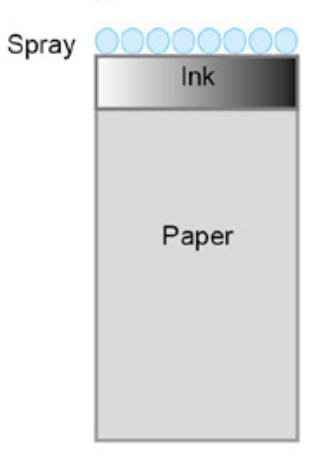

C

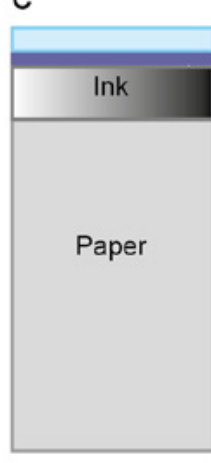

d

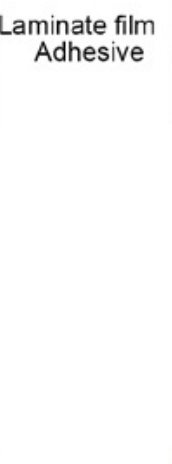

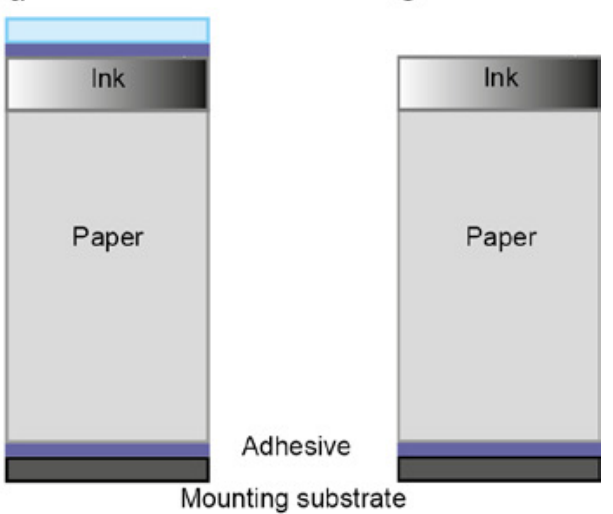

Figure 4. Examples of mounting systems employed in digital printing: $a$ ) Digital print as obtained from the printer; $b$ ) Print with protective spray on the image surface; $c$ ) Face-mounted print; $d$ ) Encapsulated print; $e$ ) Paper substrate mounted on a rigid supporting material.

art fair catalogues, there is no agreement to name these type of artworks. According to this, usually employed terms could be classified into the following four categories 1) Generalist descriptions: print, digital print; 2) Proprietary or commercial names: Diasec, Digigraphie, Ultrachrome, Giclée; 3) Confusing terms: archival print, archival pigment print; and 4) Incorrect definitions: ink on paper, pigment on paper, pigment print. None of them describes clearly the materiality of the object, so more than a cataloguing problem, this issue can cause important matters in the conservation decision-making of the artworks.

Precise naming should gather specific information about the prints, exempt of commercial trademarks or indicating them as complementary data, and ranging from generic terms to precise ones, according to the needs. In this way, the first term should be a general one such as "digital print", followed by the printing technology -electrophotography, inkjet or thermal -, the type of substrate, and if needed, specifications about finishing and mounting techniques [38].

Aware of the situation some institutions have been doing research on the characterization and permanence of these printed images for some time now. Among them, the well-known Image Permanence Institute (IPI) of the Rochester Institute of Technology (RIT) develops sustainable practices for the preservation of images and cultural heritage. It presents basic information on digital prints through the Digital Print Preservation Portal (DP3), a web for didactic purposes [39], and Graphics Atlas, a resource also available on the Internet that serves as a starting point for the identification and characterization of prints and photography [8].

\section{The concept in contemporary art: appearance, documentation and reproduction}

Due to the complexity that digital printing presents both from the material and conceptual point of view, its conservation should not only pay attention to the materiality of the artworks. Theoretical and conceptual aspects that led the artists to produce them should be studied in-depth in order to be able to select the most appropriate strategies in each case, with the ultimate goal of keeping its authenticity intact.

The artist interview has become an indispensable resource for conservators of contemporary art [40]. Thus, Marchesi analyzes the complexity of decision-making regarding the conservation of contemporary photography and highlights the importance of the artist as one of the stakeholders for making such decisions [41].

\section{Appearance}

It is well known that usually one of the most common concerns for artists - especially for renowned ones - is how the appearance of their works is transformed over time, since the alteration of the printed surface can prevent the correct understanding of the artwork [42]. As indicated by Hunt and Pointer, four aspects are vital to evaluate the optical properties (appearance) of the surfaces: colour, brightness, texture and translucency [43].

In order to preserve the materiality of the artworks and limit as much as possible other conservation decisions such as reproduction, it is important to determine how environmental factors affect the employed materials [44]. Among a few, the IPI and the independent laboratory Wilhem Imaging Research (WIR) carry out numerous permanence tests to have a better understanding of the ageing processes occurring to the digital prints. The latter, tests products and materials for companies related to the printing industry since the mid-1990s and this information is available on the Internet [45].

Addressing other questions about conservation, such as the colour consistency in printing - an important matter to think about for printing and reproduction - the Centre for Fine Print Research (CFPR) of Bristol, a research centre created in 1998 belonging to the University of West England (United Kingdom), is considered one of the leading centres in terms of art and design research; they carry out international projects about the artistic, historical and 
industrial importance of the practices related to creative printing, processes and technologies, collaborating with a variety of professionals, institutions and companies [46].

Research studies have been performed so far to obtain a good knowledge of the materials involved in digital printing but this is mainly dedicated to the permanence of inkjet prints on paper substrates. It should be noted that the main interest has been focused on the effects produced by several extrinsic deterioration agents such as light [47-49], humidity [50], air pollutants [51-52] or the effects of abrasion [5357] in the appearance of prints. There have also been some studies on reversible mounting systems for large format photographs [58] or regarding the scratching of the acrylic surfaces used for face-mounting [59].

\section{Documentation}

The correct documentation of contemporary artworks play a fundamental role. First, it allows classifying, storing and visualizing the cultural assets of a museum or institution as well as offering a greater and better understanding of the aesthetic values, historical context, meaning and economic value of the works of art.This way, it provides information on aspects such as authenticity, exhibition system and changes in the appearance. Thus, documentation is an essential tool to monitor and manage in the most effective and efficient manner, the conservation of the artworks. In this way, it is possible to meet two of the objectives of any museum: selecting and recording information of the artworks physical characteristics, meaning, history, context, state of conservation- and update and disclose it [60]. However, this hard work requires skilled staff that sometimes only big museums can afford due to their budgets, preventing small museums from this important task. Several proposals have emerged to collect data concerning digital prints; in 2009, the Photographic Materials Group of the American Institute for Conservation (AIC) in collaboration with other institutions and professionals designed the Photographic Information Record, which has been translated into several languages with the aim to become an international standard [61].

The apparent simplicity and ease of production and reproduction of the works generated with digital printing devices may have been one of the reasons why correct graphic documentation and recording did not get the deserved attention until a few years ago.

For some time now, museums and other institutions have digitized their collections to make them available to a wider public through online consultation, either to bring part of the Cultural Heritage to society or to allow access and consultation to a series of cultural goods that because of their delicate state of conservation cannot be examined directly. In this case, the representativeness of the artwork should be as close as possible to reality so that digitalisation maintains the qualities of the original printed surface such as tonal reproduction, neutrality, colorimetry, uniformity and resolution [62-63]. Currently, guides for digitalisation such as the Preservation Imaging Guidelines Image Quality [64] created within the Metamorfoze project, and the Technical Guidelines for Digitizing Cultural Heritage Materials: Creation of Raster Image Master Files created in the United States by the Federal Agencies Digitization Initiative (FADGI) - Still Image Working Group [65] are being employed.

\section{Reproduction}

What happens when the artwork is irreversibly deteriorated and reproduction is selected as a conservation strategy?

Obtaining an image matching the initial state of the artwork and maintain its authentic characteristics is a complex process because sometimes is not possible to find similar materials due to the rapid market development. Moreover, it is essential to follow an appropriate colour management method to ensure that the new copy reproduces the original idea of the artist as much as possible [66-67].

Digital technologies allow for capturing, storing and working the images in such a way that the process itself can provide a guarantee concerning colour accuracy. To ensure consistency and quality in the process, the perceptual evaluation carried out by experts does not turn out to be sufficiently precise when dealing with cultural heritage, for this reason, it is necessary to apply a specific workflow [68]. As previously mentioned, colour reproduction is one of the most important aspects to take into account, therefore, the process should be reproducible and allow checking and registering every step, but also should verify its quality, avoiding subjective interpretations of the images [69-70].

\section{Conclusion}

Research about digital printing related to art is a complex field addressing specific technologies, inks, substrates, finishes and mounting systems which interact to generate an image; different combinations produce distinct images that will influence in their conservation in a particular way.

In addition, conceptual features related to the artists' intent should be also taken into account in order to obtain an accurate conservation plan that fulfils the current conservation theories. For that, a common and a correct terminology seems to be the first obstacle to overcome, followed by an accurate documentation and recording methodologies. This will enable a precise and overall knowledge about the employed materials and physical properties of the images such as colour. These aspects are covered in a very different way when comparing big museum and institutions, which have more resources, and smaller ones, so it would be necessary to develop affordable strategies for the latter.

While research has been conducted about the ageing of digital prints on paper substrates, protective or mounting systems applied to them have been hardly studied nor their effects on their permanence. Moreover, printing on rigid 
substrates (plastics, metals, wood, glass...) is becoming more popular among artists because of the advantages they offer, but their stability over time has not yet been proven in this context, neither the ideal conditions for their correct storage, the deterioration they can show and how to solve the related problems.

Works that combine digital prints with other more traditional techniques in the arts such as painting (oil, acrylic paint, watercolours, pencils...) or engraving (lithography, etching, silkscreen...) give the art pieces a more experimental nature and also singular characteristics that concern their conservation. As they are very particular processes, they have not been properly studied.

Because there have been so many options available for artists and more being developed, more research is needed to fully understand what might be encountered in a collection.

\section{REFERENCES}

1. Noll, A.M. The Beginnings of Computer Art in the United States: A memoir', Computers \& Graphics 19(4) (1995) 495-503, https://doi.org/10.1016/0097-8493(95)00026-9.

2. Mason, C. A Computer in the Art Room. The Origins of British Computer Arts 1950-1980, JJG Publishing, London (2008).

3. Rush, M. New Media in Late 2oth-Century Art, Thames \& Hudson, London (1999).

4. Lieser, W. Arte Digital. Nuevos Caminos en el Arte, H.F. Ullmann, Potsdam (2010).

5. Jürgens, $M$. 'The history and conservation of digital prints', The Getty Conservation Institute Newsletter 22(3) (2007) 4-9, https://www.getty.edu/conservation/publications_resources/ newsletters/pdf/v22n3.pdf (accessed 2020-02-17).

6. Muñoz, S. Teoría Contemporánea de la Restauración, Síntesis, Madrid (2003).

7. Jürgens, M. The Digital Print. Identification and Preservation, The Getty Conservation Institute, Los Angeles (2009).

8. Image Permanence Institute, Graphics Atlas (2009), http:// www.graphicsatlas.org/ (accessed 2016-10-11).

9. Kipphan, H. ed., Handbook of Print Media. Technologies and Production Methods, Springer-Verlag, Berlin (2001).

10. Dyamond, A.S.; Weiss, D.S. eds., Handbook of Imaging Materials, Marcel Dekker, New York (2002).

11. Singh, M; Haverinen, H.M.; Dhagat, P.; Jabbour, G.E., 'Inkjet printing - Process and Its applications', Advanced Materials $\mathbf{2 2}$ (2010) 673-684, https://doi.org/10.1002/adma.201090011.

12. Castrejon-Pita, J.R.; Baxter, W.R.S.; Morgan, J.; Temple, S.; Martin, G.D.; Hutchings, I.M., 'Future, Opportunities and Challenges of Inkjet Technologies', Atomization and Sprays 23(6) (2013) 541-565, https://doi.org/10.1615/ AtomizSpr.2013007653.

13. Soler, A.; Castro, K., Impresión Piezoeléctrica: La Estampa Inyectada. Algunas Reflexiones en torno a la Gráfica Digital, Universidad de Vigo, Vigo (2006).

14. European Specialist Printing Manufacturers Association [ESMA], The inkjet conference (2019), https://www.esma.com/ (accessed 2019-6-12).

15. Drupa, Printing trade fair (2019), https://www.drupa.com/ (accessed 2019-6-12).
16. Magdassi, S. (Ed.), The Chemistry of Inkjet Inks, World Scientific Publishing Co., Singapore (2010).

17. Pekarovicova, A.; Bhide, H.; Fleming, P.; Pekarovic, J., 'Phasechange inks', Journal of Coating Technology 75(936) (2003) 65-72, https://doi.org/10.1007/BF02697924.

18. T. Martin, Dye-based or pigment-based? Debunking the myths of digital inks, Digital photo techniques, March/April (2004) 49-60, http://www.ink2image.com/files/Photo Techniques_article.pdf (accessed 2020-02-17).

19. Wilhelm, H., 'A 15-year history of digital printing technology and print permanence in the evolution of fine art photography- from 1991 to 2006', NIP 22: The 22nd International Conference on Digital Printing Technologies. Final program and Proceedings, The Society for Imaging Science and Technology, Springfield (2006) 308-315.

20. Lavery, A.; Provost, J., 'Color-media interactions in ink jet printing', in Recent Progress in Ink Jet Technologies II, ed. E. Hanson, The Society for Imaging Science and Technology, Springfield (1999) 400-405.

21. Yuan, S.; Sargeant, S.; Rundus, J.; Jones, N.; Nguyen, K., 'The development of receiving coatings for inkjet imaging applications', in Recent Progress in Ink Jet Technologies II, ed. E. Hanson, The Society for Imaging Science and Technology, Springfield (1999) 378-382.

22. Yip, K.; Lubinsky, A.; Perchak, D.; Ng, K., 'Measurement and modelling of drop absorption time for various ink-receiver systems', Journal of Imaging Science and Technology 47(5) (2002) 388-393.

23. Hofmann, R., 'Surface science in photography', Nanotechnology Perceptions 11 (2015) 5-11.

24. St Cuthberts Mill Paper, Digital fine art (2019), http://www. stcuthbertsmill.com/ (accessed 2019-6-10).

25. Hahnemühle, Digital fine art (2019), https://www. hahnemuehle.com/en/hahnemuehle.html (accessed 2019-610).

26. Canson, Canson infinity digital fine art \& photo (2019), http:// www.canson-infinity.com/en (accessed 2019-6-10).

27. Epson, Photograhpic \& fine art papers, (2019) https://epson.com/ signature-worthy-fine-art-photo-papers (accessed 2019-6-10).

28. HP, Fine art printing materials (2019), https://hp.globalbmg. com/uk/fine-art-printing-materials (accessed 2019-6-10).

29. Tecco, Tecco photo (2019), https://www.tecco.de/productcategory/tecco/tecco-photo/ (accessed 2019-6-10).

30. Pénichon, S. 'Mounting substrates for contemporary photographs', Studies in Conservation 49(sup2) (2004) 114-118, https://doi.org/10.1179/sic.2004.49.s2.025.

31. Pénichon, S.; Jürgens, M., 'Two finishing techniques for contemporary photographs', Topics in Photographic Preservation 9 (2001) 85-96.

32. Pénichon, S.; Jürgens, M.; Murray, A., 'Práticas de montagem de fotografías contemporáneas', Cadernos Técnicos de Conservação Fotográfica, Vol. 7, Funarte, Rio de Janeiro (2010), http://portais.funarte.gov.br/preservacaofotografica/wpcontent/uploads/2012/02/Cadernos_Tecnicos_7.pdf (accessed 2020-02-17)

33. Smith, M. 'Face-mounting techniques for contemporary photographs and digital images', 7th AICCM Book, Paper and Photographic Materials Symposium, Melbourne (2012) 75-81.

34. Pénichon, S.; Jürgens, M.; Murray, A., 'Light and dark stability 
of laminated and face-mounted photographs: a preliminary Investigation', Studies in Conservation 47(sup3) (2002) 154-159, https://doi.org/10.1179/sic.2002.47.s3.032.

35. Zorn, S.; Dobrusskin, S., 'Diasec and other finishing techniques - investigation of accelerated light fading', Studies in Conservation 56(84) (2011) 257-266, https://doi.org/10.1179/20 $4705811 X 13159282692842$.

36. Blaschke-Walther, K.; Dobrusskin, S., 'Unmounted versus face-mounted inkjet prints. Analyses concerning their light ageing behaviour', Journal of Paper Conservation 16(1) (2015) 9-17, https://doi.org/10.1179/1868086015Z.0000000001.

37. Burge, D.; Nishimura, D.; Estrada, M., 'What do you mean when you say digital print?', Archival Outlook, March/ April (2009) 6-25.

38. Anthonisen-Añabeitia, I.; Maguregui, I., 'Conservation Strategies for digitally printed artworks', IMPACT 10. International Multidisciplinary Printmaking Conference, Santander (2018) 298-301.

39. Image Permanence Institute. (2007). Digital print preservation portal (DP3), http://www.dp3project.org/ (accessed 2016-10-15).

40. Beerkes, L.; 't Hoen, P.; Hummelen, I.,et al., The Artist Interview for Conservation and Preservation of Contemporary Art. Guidelines \& Practice, Jap Sam Books, Heijningen (2012).

41. Marchesi, M., 'Forever Young. The reproduction of photographic artworks as a conservation strategy', $\mathrm{PhD}$ dissertation, Leiden University, Leiden (2017).

42. Stigter, S., 'Through the conservator's lens: from analogue photowork to digital printout: How is authenticity served?', in Authenticity in Transition: Changing Practices in Contemporary Art Making and Conservation, eds. E. Hermens \& F. Robertson, Archetype Publications, Glasgow (2016) 169-178.

43. Hunt, R.W.G.; Pointer, M.R., Measuring Colour, 4th ed., Wiley, Chichester (2011).

44. Fenech, A.; Dillon, C.; Ntanos, K.; Bell, N.; Barrett, M.; Strlič 'Modelling the lifetime of colour photographs in archival collections', Studies in Conservation 58(2) (2013) 107-116, https:// doi.org/10.1179/2047058412Y.0000000081.

45. Wilhelm, H. Wilhelm imaging research (2002), http://wilhelmresearch.com/ (accessed 2019-1-10).

46. University of West England (2019) Centre for fine print research, https://www.uwe.ac.uk/sca/research/cfpr/ (accessed 2019-3-8).

47. Parraman, C. 'Colour changes in prints during long-term dark storage of prints', J. Phys.: Conf. Ser. 231012006 (2010), https:// doi.org/10.1088/1742-6596/231/1/012006.

48. Venosa, A.; Burge, D.; Nishimura, D., 'Effect of Light on modern digital prints photographs and documents', Studies in Conservation 56(4) (2011) 267-280, https://doi.org/10.1179/20470 $5811 X 13159282692888$.

49. Venosa, A.; Burge, D.; Salesin, E., 'Light-induced cracking and abrasion of inkjet prints: Damage and mitigation', Studies in Conservation, 61(sup1) (2016), 94-100, https://doi.org/10.1179/204 $7058415 \mathrm{Y} .0000000023$.

50. Burge, D.; Scott, J., 'Resistance of digitally and traditionally printed materials to bleed, delamination, gloss change, and planar distortion during flood', Journal of the American Institute for Conservation, 51(2) (2012), 145-158, https://doi. org/10.1179/019713612804860419.

51. Burge, D.; Gordeladze, N.; Bigourdan, J.L.; Nishimura, D., 'Effects of nitrogen dioxide on the various digital print technologies: photographs and documents', NIP27 \& Digital Fabrication Conference. International Conference on Digital Printing Technologies, The Society for Imaging Science and Technology, Springfield (2011) 205-208.

52. Burge, D.; Gordeladze, N.; Nishimura, D.; Bigourdan, J.L., 'Mitigation of pollution-induced deterioration of digital prints through low-temperature storage', NIP29 \& Digital Fabrication Conference. International Conference on Digital Printing Technologies, The Society for Imaging Science and Technology (2013) 44-47.

53. Burge, D.; Venosa, A.; Salesin, G.; Adelstein, P.; Reilly, J., 'Beyond lightfastness: some neglected issues in permanence of Ddgital hardcopy', in International Symposium on Technologies for Digital Fulfillment, Society for Imaging Science and Technology, Las Vegas (2007) 61-64.

54. Breitung, E., 'Survey of abrasion resistant acrylics and polycarbonates for face mounted photographs', Topics in Photographic Preservation 12 (2007) 114-125, http://resources. conservation-us.org/pmgtopics/2007-volume-twelve/12_18_ Breitung.html (accessed 2020-02-17).

55. Salesin, E.; Scott, J.; Nishimura, D.; Adelstein, P.; Reilly, J.; Burge, D., 'Abrasion of digital reflection prints', NIP24 \& Digital Fabrication Conference. International Conference on Digital Printing Technologies, The Society for Imaging Science and Technology, Springfield (2008) 228-230.

56. Nishimura, D.; Salesin, G.; Adelstein, P.; Burge, D., 'Abrasion of digital reflection prints: the abrasiveness of common surfaces and the vulnerability of print processes', The Book and Paper Group Annual, 28, eds. J. Hinz, R. Homer \& O. Dann, American Institute for Conservation of Historic and Artistic Works (AIC), Philadelphia (2009) 47-52.

57. Salesin, E.; Burge, D., 'The determination of the minimum force to initiate abrasion damage of digitally printed documents and photographs', NIP29 \& Digital Fabrication Conference. International Conference on Digital Printing Technologies, The Society for Imaging Science and Technology, Springfield (2013) 56-59.

58. Chen, J.; Herrera, R.; Ravines, P.; Wiegandt, R.; Penichon, S.; Sirven, M., 'Reversible Mounting Techniques for the Display of Large-Format Contemporary Photographs', Topics in Photographic Preservation 12 (2007) 131-140, http://resources. conservation-us.org/pmgtopics/2007-volume-twelve/12_20_ Chen.html (accessed 2020-02-17).

59. Kim, E.; Breitung, E., 'Scratch Rrepair on acrylics used in facemounted photographs: a survey of materials and techniques', Topics in Photographic Preservation, 12 (2007) 144-159, http:// resources.conservation-us.org/pmgtopics/2007-volumetwelve/12_23_kim.html (accessed 2020-02-17).

60. Scholte, T.; Wharton, G. eds., Inside Installations. Theory and Practice in the Care of Complex Artworks, Amsterdam University Press, Amsterdam (2011).

61. American Institute for Conservation (2009), Photographic information record, http://www.conservation-us.org/resources/ our-publications/specialty-group/photographic-materials/ photographic-information-record\#.WrJGe9IV_IU (accessed 2018-03-08).

62. Robledano, J., 'Modelos de calidad en la digitalización de patrimonio fotográfico', Del Artefacto Mágico al Megapixel. Estudio de Fotografía, eds. M. Olivera \& A. Salvador, 


\section{Anthonisen-Añabeitia, I. M. Olabarria}

Universidad Complutense de Madrid, Madrid (2014) 367- 393.

63. Pereira, J.M., 'El control de calidad en la digitalización de bienes culturales', Revista PH 95 (2018) 63-67, https://doi. org/10.33349/2018.0.4226.

64. Dormolen, H., Metamorfoze preservation imaging guidelines. Image quality, version 1.0 (2010), https://www.metamorfoze.nl/sites/ metamorfoze.nl/files/publicatie_documenten/Metamorfoze_ Preservation_Imaging_Guidelines_1.o.pdf (accessed 2019-0224).

65. Williams, D.; Stelmach M. eds., Technical guidelines for digitizing cultural heritage materials: creation of raster image master files (2010), http://www.digitizationguidelines.gov/guidelines/ FADGI_Still_Image-Tech_Guidelines_2010-08-24.pdf (accessed 2019-02-24)

66. Westland, S., 'New developments in colour management', in IMPACT 6, International Multidisciplinary Printmaking Science, ed. S. Hoskins, Bristol (2009) 66-69.

67. Berns, R.S., Color Science and the Visual Arts. A Guide for Conservatiors, Curators, and the Curious, The Getty Conservation Institute, Los Angeles (2016).

68. Pereira, J.M., Gestión del Color en Proyectos de Digitalización. Fundamentos y Estrategias para la Fidelidad del Color, Ediciones técnicas Marcombo, Barcelona (2013).

69. Homann, J.P., Digital Color Management. Principles and Strategies for the Standardized Print Production, Springer-Verlag, Berlin (2009).

70. Santos, J.M., 'El color en la reproducción fotográfica en proyectos de conservación, en Proyectos y Actuaciones', Revista PH 86 (2014) 102-123, https://doi.org/10.33349/2014.0.3511.
RECEIVED: 2019.8.13

REVISED: 2019.11 .13

ACCEPTED: 2020.1.6

ONLINE: 2020.5.13

\section{(ब) $\Theta$}

This work is licensed under the Creative Commons Attribution-NonCommercial-NoDerivatives 4.0 International License. To view a copy of this license, visit

http://creativecommons.org/licenses/by-nc-nd/4.o/deed.en. 